\title{
Anti-inflammatory function of arctiin by inhibiting COX-2 expression via NF- $\kappa$ B pathways
}

\author{
Sungwon Lee ${ }^{1}$, Seulmee Shin ${ }^{1}$, Hyunyul Kim¹, Shinha Han¹, Kwanghee Kim, Jeunghak Kwon', Jin-Hwan Kwak², \\ Chong-Kil Lee ${ }^{3}$, Nam-Joo Ha ${ }^{1}$, Dongsool Yim ${ }^{1}$ and Kyungjae Kim
}

\begin{abstract}
Background: Arctiin, isolated from Forsythia suspensa has been reported to have anti-inflammatory, anti-oxidant, antibacterial, and antiviral effects in vitro. However, there has been a lack of studies regarding its effects on immunological activity. The aim of this study is to investigate the anti-inflammatory potential and possible mechanisms of arctiin in LPS-induced macrophages.

Methods: We investigated the mRNA and protein levels of proinflammatory cytokines through RT-PCR and western blot analysis, followed by a FACS analysis for surface molecule changes.

Results: Arctiin dose dependently decreased the production of NO and proinflammatory cytokines such as IL-1 $1 \beta$, IL-6, TNF- $\alpha$, and PGE 2 , and it reduced the gene and protein levels as determined by RT-PCR and western blot analysis, respectively. The expression of co-stimulatory molecules such as B7-1 and B7-2 were also inhibited by arctiin. Furthermore, the activation of the nuclear transcription factor, NF- $\kappa$ B in macrophages was inhibited by arctiin.
\end{abstract}

Conclusion: Taken together these results provide evidence of the bioactivity of arctiin in inflammatory diseases and suggest that arctiin may exert anti-inflammatory effect by inhibiting the pro-inflammatory mediators through the inactivation of NF-kB.

\section{Background}

Non-steroidal anti-inflammatory drugs (NSAIDs) have been widely used in the treatment of acute and chronic inflammatory diseases, which play their therapeutic effects via inhibiting cyclooxygenase (COX) to prevent the production of pro-inflammatory prostaglandins. However, their long-term use shows the major side-effects of gastrointestinal diseases. Thus researchers have tried to screen new biological components from various plant sources including medicinal plants which inhibited COX with lower toxicity and higher anti-inflammatory activity on the great deal in the therapeutic application [1].

The fruit of Forsythia suspensa Vahl, Forsythiae Fructus, has been widely used in traditional medicines to treat swelling, gonorrhea, urination, hemorrhoids, tubercle, and other afflictions [2]. Arctiin is a lignan compound isolated from Forsythiae Fructus (Figure 1A); it has been

\footnotetext{
*Correspondence: kimkj@syu.ac.kr

'College of Pharmacy, SahmYook University, Seoul 139-742, Republic of Korea

Full list of author information is available at the end of the article
}

found to significantly induce cell detachment and decrease the number of $\mathrm{PC}-3$ cells in human prostate cancer [3]. Moreover, it has been demonstrated to possess many kinds of bioactivities [4] and a number of important pharmacological properties including being demutagenic $[5,6]$ cytotoxic, anti-proliferative $[7,8]$, platelet activating factor (PAF) antagonistic [9], calcium antagonistic [10], and anti-carcinogenetic. In animal studies, arctiin effectively inhibited the formation of 12-Otetradecanoylphorbol-13-acetate (TPA)-induced ear edema in mice [11]. However, there has been a lack of studies regarding the effects of arctiin on inflammation.

Chronic inflammation and infection has been demonstrated to lead to an upregulation of a series of enzymes and signaling proteins in affected tissues and cells. Inflammation has been shown to be a multi-step process, mediated by activated inflammatory and immune cells including macrophages and monocytes [12]. Inflammatory reactions, phagocytosis, natural cytotoxicity, cytokine production, antibody response, and cellular immunity are defensive mechanisms that have been suggested to be
C Biomed Central

(ㄷ) 2011 Lee et al; licensee BioMed Central Ltd. This is an Open Access article distributed under the terms of the Creative Commons Attribution License (http://creativecommons.org/licenses/by/2.0), which permits unrestricted use, distribution, and reproduction in any medium, provided the original work is properly cited. 
<smiles>COc1ccc(CC2COC(=O)C2Cc2ccc(O)c(OC)c2)cc1O</smiles>

B

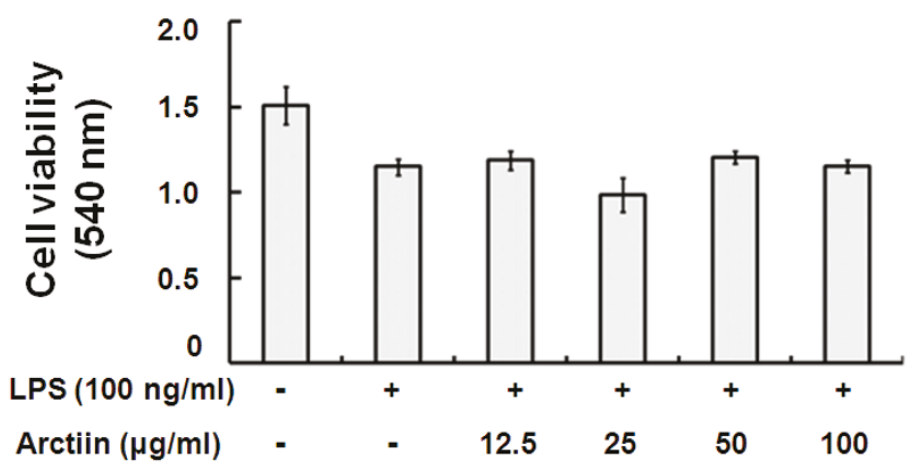

Figure 1 Structure of arctiin (A); Cell viability (B). Cell viability was evaluated as described in 'Materials and Methods'.

modulated by therapeutic doses of antimicrobial agents [13]. Activated macrophages include the inducible forms of nitric oxide synthase (iNOS) and cyclooxygenase- 2 (COX-2), which have been reported to be responsible for increasing the levels of nitric oxide $(\mathrm{NO})$ and prostaglandins (PGs), the overproduction of proinflammatory cytokines (e.g. TNF- $\alpha$, IL-6, IL-1 $\beta$ ) and inflammatory mediators (e.g. $\mathrm{PGE}_{2}, \mathrm{NO}$ ), and the mediation of many inflammatory diseases [14].

Costimulatory molecules are one class of receptors, which have recently been implicated as fulfilling this role in the innate immune response. B7-1 and -2 represent one class of costimulatory receptors. They consist of structurally related, cell-surface protein ligands, which bind to receptors on lymphocytes that regulate immune responses. In addition, they are stimulated via CD28 while CTLA4 serves as both a stoichiometric inhibitor of CD28-B7-1/-2 engagement as well as serving to directly induce immunosuppressive signals within dendritic cells [15].

In this study, we evaluated the potential of arctiin as a therapeutic modality for inflammation in RAW264.7 mouse macrophage cells as well as in primary peritoneal macrophages. Our results demonstrated that arctiin largely inhibited the excessive production of inflammatory mediators such as NO, PGE 2 , TNF- $\alpha$, IL- $1 \beta$ and IL- 6 as well as the suppression of COX-2 through the inhibition of NF-kB translocation pathway.

\section{Methods}

\section{Chemicals and reagents}

Dulbecco's Modified Eagle Medium (DMEM)-1640, fetal bovine serum (FBS), and penicillin/streptomycin were purchased from Hyclone (Logan, USA). Escherichia coli lipopolysaccharide (LPS) was purchased from sigma (St. Louis, USA). $\beta$-actin, i-NOS, COX-2, p65, p-I $\kappa \mathrm{B} \alpha, \mathrm{PE}-$ B7-1, and FITC-B7-2 anti-bodies were purchased from
BD Pharmingen ${ }^{\mathrm{TM}}$ (San Jose, USA). Enzyme immunoassay kits for the measurement of PGE ${ }_{2}$, IL- $1 \beta$, IL-6, and TNF- $\alpha$ were purchased from R\&D system (Minneapolis, USA).

\section{Isolation of arctiin from Forsythiae Fructus}

Forsythiae Fructus obtained from an herbal market in Seoul, Korea, was extracted three times with hot $\mathrm{MeOH}$ ( 3 hours) and then evaporated at $40^{\circ} \mathrm{C}$ under reduced pressure to dryness. The $\mathrm{MeOH}$ extract was then resuspended in distilled water and successively partitioned with $\mathrm{CHCl}_{3}, \mathrm{EtOAc}$, and n-BuOH. The $\mathrm{BuOH}$ fraction was then loaded onto a silica gel column and eluted with $\mathrm{MeOH}-\mathrm{CHCl}_{3}$ mixtures (1:5 to $\left.1: 1\right)$. The result was white amorphous powders, which were identified as authentic samples using spectrometric data of nuclear magnetic resonance $\left({ }^{1} \mathrm{H}-\mathrm{NMR}\right)$, mass spectrometry (MS). ${ }^{1} \mathrm{H}-\mathrm{NMR}(300 \mathrm{MHz}), \mathrm{DMSO}-\mathrm{d}_{6}: \delta 6.97(1 \mathrm{H}, \mathrm{d}, J$ $=8.3, \mathrm{H}-5), 6.82\left(1 \mathrm{H}, \mathrm{d}, \underline{\mathrm{J}}=8.0, \mathrm{H}-5^{\prime}\right), 6.77(1 \mathrm{H}, \mathrm{d}, J=$ $1.7, \mathrm{H}-2), 6.65(1 \mathrm{H}, \mathrm{dd}, J=8.3,1.7, \mathrm{H}-6), 6.65(1 \mathrm{H}, \mathrm{s}$, H-2'), $6.59\left(1 \mathrm{H}, \mathrm{dd}, J=8.0,1.8, \mathrm{H}-6^{\prime}\right), 4.83(1 \mathrm{H}, \mathrm{d}, J=$ 7.3, H-1"), $4.00\left(2 \mathrm{H}, \mathrm{m}, \mathrm{H}-9^{\prime}\right), 3.70\left(3 \mathrm{H}, \mathrm{s}, \mathrm{OCH}_{3}\right), 3.69$ $\left(6 \mathrm{H}, \mathrm{s}, \mathrm{OCH}_{3}\right), 2.76\left(2 \mathrm{H}, \mathrm{m}, \mathrm{H}-7^{\prime}\right), 2.54(4 \mathrm{H}, \mathrm{m}, \mathrm{H}-7,8$, $\left.8^{\prime}\right)$. Positive FABMS $(m / z): 557\left(\mathrm{M}+\mathrm{Na}^{+}\right), 372(\mathrm{M}+$ gluco), 154, 136. The white amorphous powder compound analyzed by NMR and MS was identified to arctiin (Figure 1A).

\section{Animals}

ICR mice (6-8 weeks old, specific pathogen-free) were obtained from Orient-Bio Co. (Seongnam, Korea). Animals were fed with standard laboratory chow (PMI Lab Diet, Richmond, USA) and autoclaved distilled water (DW). They were acclimatized in an animal facility (Sahmyook University, Korea) and maintained at $22 \pm 2^{\circ} \mathrm{C}$ in $50 \pm 10 \%$ relative humidity and a light/dark $(12 \mathrm{hrs} / 12$ hrs) cycle for at least 7 days prior to the experiments. 


\section{Cell culture}

Male ICR mice (6-8 weeks) were intraperitoneally injected with $1.5 \mathrm{ml}$ thioglycollate broth for recruitment of macrophages. RAW 264.7 cells were obtained from the American Type Culture Collection (ATCC, Rockville, USA). These cells were grown at $37^{\circ} \mathrm{C}$ in DMEM medium supplemented with $10 \%$ FBS and $1 \%(\mathrm{v} / \mathrm{v})$ penicillin $(10,000 \mathrm{U} / \mathrm{ml}) /$ streptomycin $(10,000 \mathrm{U} / \mathrm{ml})$ in a humidified $5 \% \mathrm{CO}_{2}-95 \%$ air incubator under standard conditions.

\section{Cell viability assay}

A commercially available cell viability assay was employed to evaluate the cytotoxic effect of arctiin using thiazolyl blue tetrazolium bromide (SIGMA, USA). RAW264.7 cells $\left(2 \times 10^{5}\right.$ cells/well $)$ were plated with various concentrations of arctiin in 96-well microtiter plates (Nunc, Roskilde, Denmark) and were then cultured at $37^{\circ} \mathrm{C}$ in a $5 \% \mathrm{CO}_{2}$ incubator. Subsequently, $50 \mu \mathrm{l}$ of MTT solution was added to each well, and the cells were then cultured for $4 \mathrm{hrs}$ at $37^{\circ} \mathrm{C}$ in the same incubator. Following this, $100 \mu \mathrm{l}$ of solubilized solution were added to each well and the plate was allowed to stand overnight in the incubator. The optical density (OD) was then measured at $560 \mathrm{~nm}$ by a microplate reader (Molecular devices, USA).

\section{Nitrite measurement}

RAW 264.7 cells were added to each well $(200 \mu \mathrm{l} ; 1 \times$ $10^{6}$ cells $/ \mathrm{ml}$ ) of a flat-bottomed 96-well plate according to the following treatment condition: LPS $(100 \mathrm{ng} / \mathrm{ml})$, LPS/arctiin $(12.5,25,50,100 \mu \mathrm{g} / \mathrm{ml})$, and media only (DMEM-10). Nitric oxide was measured in culture supernatants by reaction with the Griess reagent (1\% sulfanilamide and $0.1 \% \mathrm{~N}$-[1-naphthy]-ethylenediamine dihydrochloride in $5 \%$ phosphoric acid; Roche) to $100 \mu \mathrm{l}$ of culture supernatant for $15 \mathrm{~min}$ at room temperature in the dark. The absorbance at $540 \mathrm{~nm}$ was then determined using a microplate reader (Molecular devices, USA) and a standard curve was generated using $\mathrm{NaNO}_{2}$.

\section{Determination of pro-inflammatory cytokines and $\mathrm{PGE}_{2}$}

RAW 264.7 cells and primary macrophages were cultured in 12-well flat plates at a density of $5 \times 10^{6}$ cells/ well. The cells were then treated with various concentrations of arctiin and subsequently stimulated with LPS $(100 \mathrm{ng} / \mathrm{ml})$ at $37^{\circ} \mathrm{C}$ for $48 \mathrm{hrs}$ in humidified air with $5 \%$ $\mathrm{CO}_{2}$. The supernatants were then collected and measured for TNF- $\alpha$, IL- $1 \beta$, IL- 6 , and PGE 2 by an enzymelinked immunosorbent assay (ELISA) according to the manufacturer's protocol.

RT-PCR (reverse transcription polymerase chain reaction) Total RNA was extracted from macrophages using the RNeasy Mini Kit (QIAGEN, USA) in an RNase-free environment. The reverse transcription of $1 \mu \mathrm{g}$ RNA was carried out using M-MLV reverse transcriptase (Promega, USA), oligo (dT) 16 primer, dNTP $(0.5 \mathrm{mM})$ and $1 \mathrm{U}$ RNase inhibitor. After incubation at $65^{\circ} \mathrm{C}$ for $5 \mathrm{~min}$ and $37^{\circ} \mathrm{C}$ for $60 \mathrm{~min}, \mathrm{M}-\mathrm{MLV}$ reverse transcriptase was inactivated by heating at $70^{\circ} \mathrm{C}$ for $15 \mathrm{~min}$. The polymerase chain reaction (PCR) was performed in $50 \mathrm{mM} \mathrm{KCl,} 10 \mathrm{mM}$ Tris- $\mathrm{HCl}$ (pH8.3), $1.5 \mathrm{mM} \mathrm{MgCl}_{2}$, and $2.5 \mathrm{mM} \mathrm{dNTPs}$ with 5 units of Taq DNA polymerase and $10 \mathrm{pM}$ of each primer set for IL-1 $\beta$, IL-6, TNF- $\alpha$, iNOS, and COX-2. The cDNA was amplified by 35 cycles of denaturing at $94^{\circ} \mathrm{C}$ for $45 \mathrm{~s}$, annealing at $60^{\circ} \mathrm{C}$ for $45 \mathrm{~s}$, and extension at $72^{\circ} \mathrm{C}$ for $1 \mathrm{~min}$. Final extension was performed at $72^{\circ} \mathrm{C}$ for 5 min. The PCR products were electrophoresed on $1.5 \%$ agarose gels and stained with ethidium bromide. The primer sequences were as follows: 5'- AGC TCC TCC CAG GAC CAC AC-3' (forward), 5'-ACG CTG AGT ACC TCA TTG GC-3' (reverse) for i-NOS, 5'-AAG AAG AAA GTT CAT TCC TGA TCC C-3' (forward), 5'-TGA CTG TGG GAG GAT ACA TCT CTC-3' (reverse) for COX-2, and 5'-GTG GGC CGC CCT AGG ACC AG-3' (forward), 5'- GGA GGA AGA GGA TGC GGC AG T-3' (reverse) for $\beta$-actin as a control for PCR. The band intensity was quantified by densitometric analysis (Infinity 3026, Vilber Lourmat, France).

\section{Preparation of cytosolic and nuclear extracts}

The cells were collected after culture and washed twice with cold PBS, resuspended in hypotonic buffer $(10 \mathrm{mM}$ HEPES, pH 7.9, $10 \mathrm{mM} \mathrm{KCl,} 1.5 \mathrm{mM} \mathrm{MgCl}_{2}, 0.2 \mathrm{mM}$ PMSF, $0.5 \mathrm{mM}$ DTT, $10 \mu \mathrm{g} / \mathrm{ml}$ aportinin). After $15 \mathrm{~min}$ incubation on ice, the cells were lysed by the addition of $0.1 \% \mathrm{NP}-40$ and vigorous vortexing for $1 \mathrm{~min}$. The nuclei were pelleted by centrifugation at $12,000 \times \mathrm{g}$ for $1 \mathrm{~min}$ at $4^{\circ} \mathrm{C}$ and resuspended in high salt buffer $(20 \mathrm{mM}$ HEPES, $\mathrm{pH} 7.9,25 \%$ glycerol, $400 \mathrm{mM} \mathrm{KCl}, 1.5 \mathrm{mM} \mathrm{MgCl}_{2}$, $0.2 \mathrm{mM}$ EDTA, $0.5 \mathrm{mM}$ DTT, $1 \mathrm{mM} \mathrm{NaF}, 1 \mathrm{mM}$ sodium orthovanadate). The cytosolic and nuclear extracts were stored in aliquots at $-70^{\circ} \mathrm{C}$.

\section{Western blot analysis}

RAW264.7 cells were washed with phosphate-buffered saline (PBS) and lysed using lysis buffer (1\% SDS, 1.0 $\mathrm{mM}$ sodium vanadate, $10 \mathrm{mM}$ Tris- $\mathrm{Cl}$ buffer, $\mathrm{pH} 7.4$ ) for $5 \mathrm{~min}$. Further, $20 \mu \mathrm{g}$ of protein from the cell lysates were applied to 8-12\% SDS-polyacrylamide gels and then transferred to nitrocellulose membranes. The membranes were blocked in $5 \%$ skim milk solution for 1 $h$. They were then incubated with anti-TNF- $\alpha$, anti-IL$1 \beta$, anti-IL-6, anti-iNOS, anti-COX-2, anti-p-I $\kappa \mathrm{B} \alpha$, or anti-p65 monoclonal antibodies for $2 \mathrm{~h}$ and subsequently washed 3 times with PBS. After incubation with an AP-labeled secondary antibody for $2 \mathrm{~h}$, the bands were visualized using an alkaline phosphatase substrate (VECTOR, USA). 


\section{Flow cytometry}

RAW 264.7 cells $\left(1 \times 10^{6}\right.$ cells/ ml $)$ were cultured in Petri-dishes. The cells were treated with various concentrations $(12.5,25,50,100 \mu \mathrm{g} / \mathrm{ml})$ of arctiin in the presence of LPS $(100 \mathrm{ng} / \mathrm{ml})$. The dishes were incubated at $37^{\circ} \mathrm{C}$ for overnight in humidified $5 \% \mathrm{CO}_{2}$ incubator under standard conditions. The cells were then washed with PBS. The washed cells were blocked with staining buffer containing 10\% normal mouse serum (NMS) for $20 \mathrm{~min}$ on ice. The blocked cells were incubated with co-stimulatory molecules such as B7-1 and B7-2 antibody (BD Biosciences, San Jose, USA) for 20 min on ice. The incubated cells were washed three times with staining buffer and then fixed by $1 \%$ paraformaldehyde in PBS. The fixed cells were measured by flow cytometry (Beckman coulter, Brea, USA).

\section{Statistical analysis}

All data are presented as mean \pm SEM values. Significant differences $(P<0.05)$ between groups were evaluated using a one-way analysis of variance with SPSS (Chicago, IL, USA) for Windows and Duncan's Multiple Range Test where appropriate.

\section{Results}

Prior to evaluating whether arctiin showed anti-inflammatory activity, we examined its effect on cell growth in RAW264.7 cells and found that arctiin did not affect normal cell growth at concentrations up to $100 \mu \mathrm{g} / \mathrm{ml}$ (Figure 1B). Thus, in the following experiments, arctiin was studied at concentrations up to $100 \mu \mathrm{g} / \mathrm{ml}$ in order to exclude any effects on the normal growth status of cells.

\section{Effect of arctiin on $\mathrm{PGE}_{2}$ and $\mathrm{NO}$ production in macrophages}

In the present study, we examined whether or not arctiin suppress macrophages activation induced by LPS, one of the most potent macrophages activation factors. Arctiin significantly suppressed COX-2 protein expression (Figure 2A) in LPS-stimulated RAW 264.7 cells. The pro-inflammatory mediator, $\mathrm{PGE}_{2}$ is also generated by the COX-2 enzyme in response to stimulation by LPS. Results showed that arctiin significantly inhibited $\mathrm{PGE}_{2}$ production (Figure $2 \mathrm{~B}$ ) and mRNA of COX-2 in RAW 264.7 cells (Figure 2C) and primary macrophages (Figure 2D) by western blot analyses and subsequent RT-PCR.

$\mathrm{NO}$ is known to be a pro-inflammatory mediator in inflammatory diseases. Several studies have demonstrated that overproduction of NO by iNOS was associated with inflammatory responses and also with serious disorders, including RA. Therefore, we investigated whether arctiin inhibits NO production in macrophages that were activated with LPS. Interestingly, in LPS $(100 \mathrm{ng} / \mathrm{ml})$ stimulated RAW264.7 cells, when various concentrations of
A

$\begin{array}{lllllll}\operatorname{LPS}(100 \mathrm{ng} / \mathrm{ml}) & - & + & + & + & + & + \\ \operatorname{Arctiin}(\mu \mathrm{g} / \mathrm{ml}) & - & - & 12.5 & 25 & 50 & 100 \\ \operatorname{COX}-2 & & & & \end{array}$

B

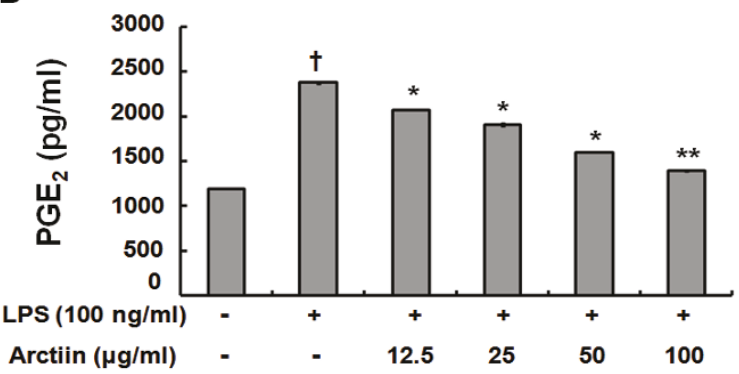

C

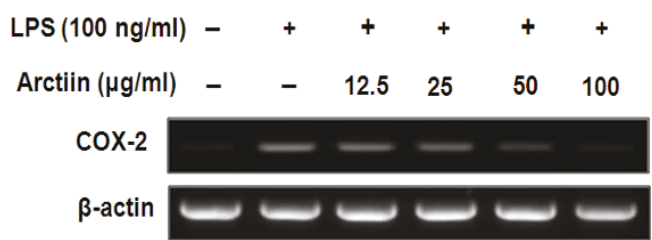

D

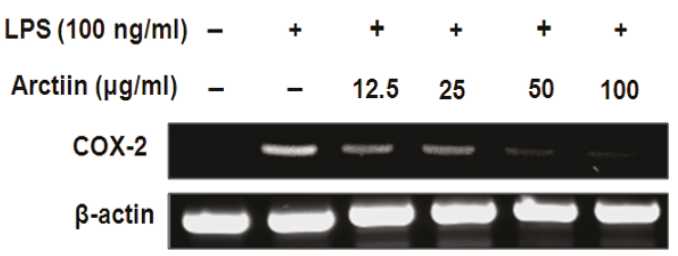

Figure 2 Arctiin inhibits the production of COX-2 (A), PGE 2 (B) and mRNA (C, D) in LPS-stimulated macrophages. RAW 264.7 cells (A-C) and primary macrophages (D) were treated with different concentrations of arctiin $(12.5 \sim 100 \mu \mathrm{g} / \mathrm{ml})$ in the presence of LPS (100 ng/ml) and was monitored as described in 'Materials and Methods'. Each bar represents the means \pm S.D. from three separate experiments. ${ }^{\dagger+} P<0.01$ compares to the control. ${ }^{*} P<0.05$, ${ }^{*} P<0.01$ compared to the LPS. 
arctiin $(12.5,25,50,100 \mathrm{uGu} / \mathrm{ml})$ were added to the culture media at the time of cell stimulation, LPS-induced production of NO was significantly inhibited in a dosedependent manner (Figure 3A). Subsequent RT-PCR and western blot analyses showed that arctiin inhibited protein expression of i-NOS (Figure 3B) and mRNA (Figure 3C) in RAW 264.7 cells as well as the primary macrophages (Figure 3D).

\section{Arctiin down-regulates production of pro-inflammatory cytokines}

The in vitro anti-inflammatory activity of arctiin was monitored by evaluating the gene and protein expression levels of inflammation-related enzymes (iNOS and COX2 ) and several proinflammatory cytokines (IL-1 $\beta$, IL-6, and TNF- $\alpha$ ) with ELISA and western blot analysis. As shown in Figure 4A, arctiin significantly suppressed the protein expression of pro-inflammatory cytokines in LPS-stimulated macrophages. Moreover, productions of cytokine were significantly attenuated by $100 \mu \mathrm{g} / \mathrm{ml}$ of arctiin in the both RAW 264.7 cells (Figure 4B, D, and F) and primary macrophages (Figure $4 \mathrm{C}, \mathrm{E}$, and D).

\section{Effect of arctiin on the expression of co-stimulatory} molecules

Adhesion molecules play an important role in the macrophage activation process. RAW264.7 cell surface expression of B7-1 and B7-2 was examined using flow cytometry. Results demonstrated that arctiin inhibited cell surface molecules in a dose-dependent manner. Further, LPS-stimulated RAW264.7 cells treated with a high concentration of arctiin $(100 \mu \mathrm{g} / \mathrm{ml})$ had a greater reduction than other concentrations (Figure 5).

\section{Effect of arctiin on the activation of NF- $\kappa \mathrm{B}$}

NF- $\mathrm{KB}$ proteins are present in the cytoplasm as inactive heterodimers composed of two subunits, P50 and P65, and are bound to the inhibitory protein $\mathrm{I} \kappa \mathrm{B} \alpha$ which prevents it from the translocation into the nucleus of the cell [16]. Upon stimulation, $\mathrm{I} \kappa \mathrm{B} \alpha$ is phosphorylated and proteolytically degraded through a $26 \mathrm{~S}$ proteasomemediated pathway which facilitates NF- $\mathrm{KB}$ translocation into the nucleus and regulates gene transcription [17]. To investigate whether arctiin could affect nuclear translocation of NF-кB, western blot analysis of NF-кB p65 was carried out using RAW264.7 cell lysates. The amount of NF-KB p65 was markedly increased upon exposure to LPS alone, whereas arctiin inhibited it (Figure 6). Furthermore, we examined how arctiin modulated translocation of NF- $\kappa \mathrm{B}$, western blot analysis of phosphorylation of $\mathrm{I}-\kappa \mathrm{B} \alpha$ in cytoplasm. Arctiin significantly attenuated $\mathrm{I} \kappa \mathrm{B} \alpha$ phosphorylation in RAW 264.7 cells (Figure 6). These results suggest that inhibition of i-NOS, IL-1 $\beta$, IL-6, TNF- $\alpha$, and COX-2 gene expression by arctiin may have been due to the down regulation of NF- $\kappa \mathrm{B}$ activation.

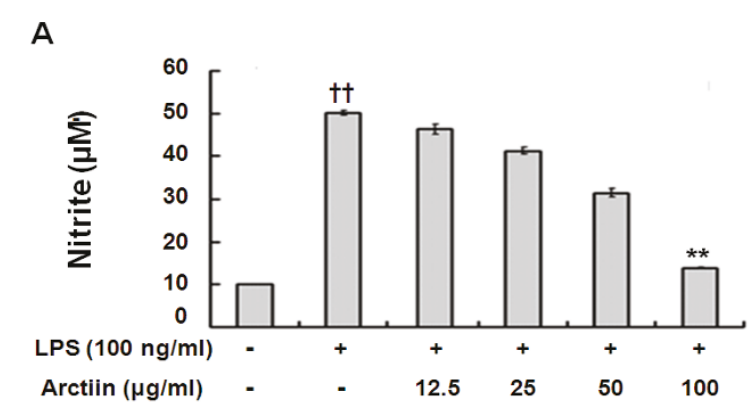

B

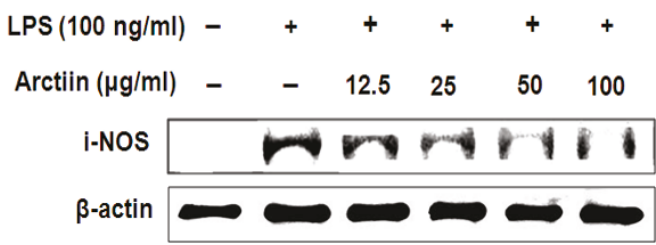

C

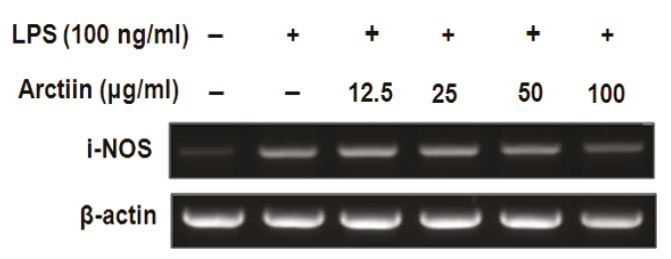

D

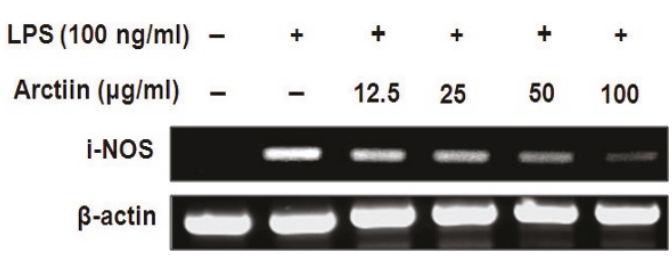

Figure 3 Arctiin inhibits the production of NO (A), expression of iNOS protein (B), and mRNA (C, D) in LPS-stimulated macrophages. RAW 264.7 cells (A-C) and primary macrophages (D) were treated with different concentrations of arctiin (12.5 100 $\mu \mathrm{g} / \mathrm{ml})$ in the presence of LPS $(100 \mathrm{ng} / \mathrm{ml})$ and was monitored as described in 'Materials and Methods'. Each bar represents the means \pm S.D. from three separate experiments. ${ }^{t \dagger} P<0.01$ compares to the control. ${ }^{* *} P<0.01$ compared to the LPS. 


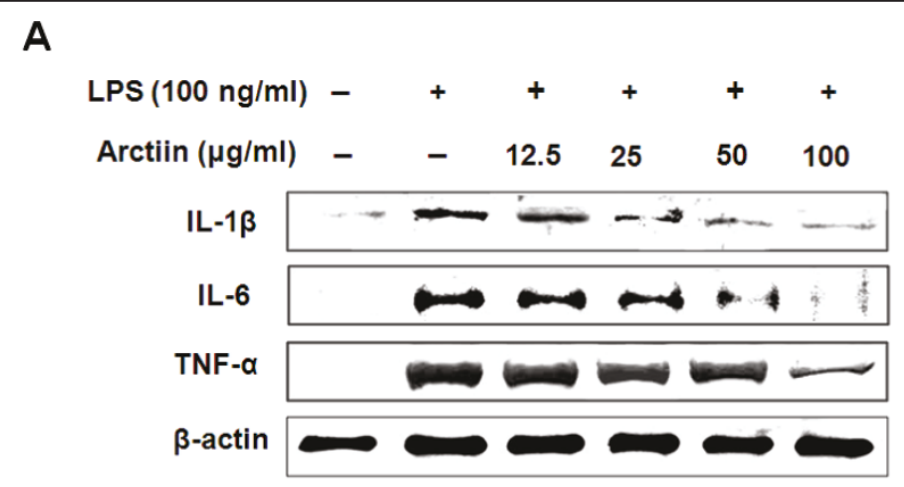

B

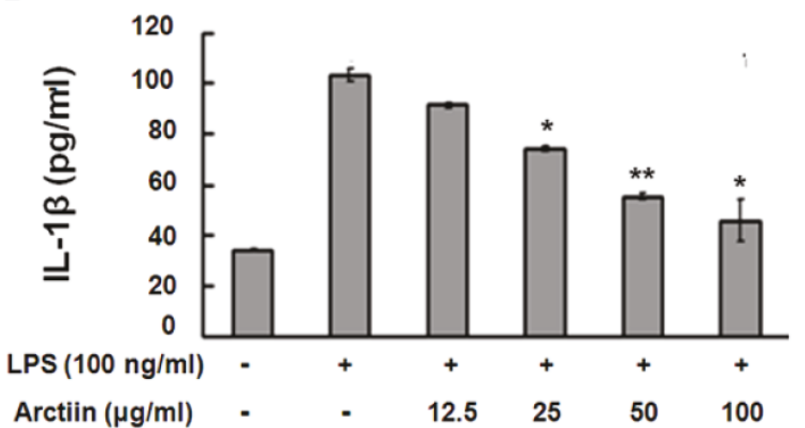

D

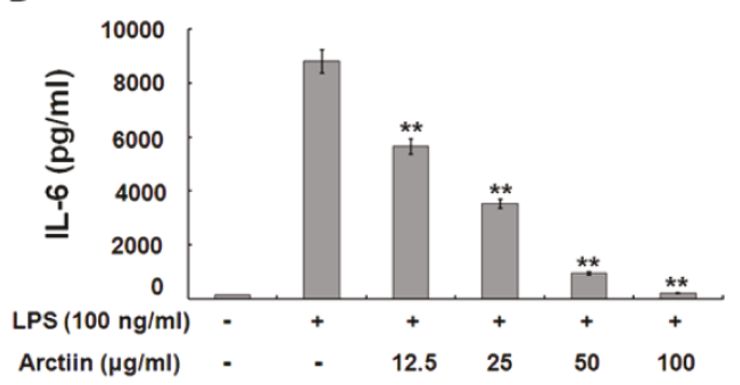

$\mathbf{F}$

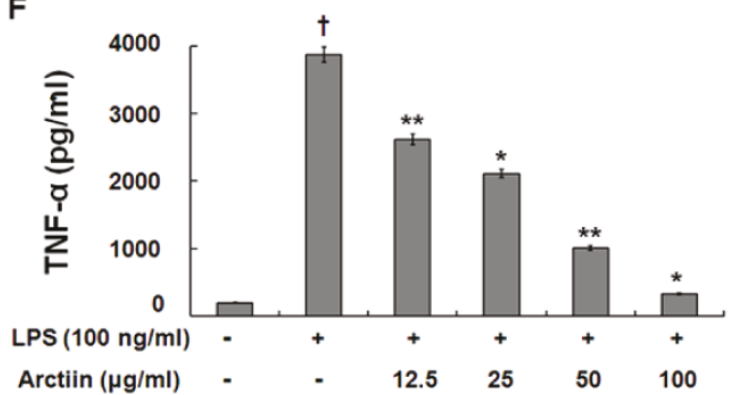

C

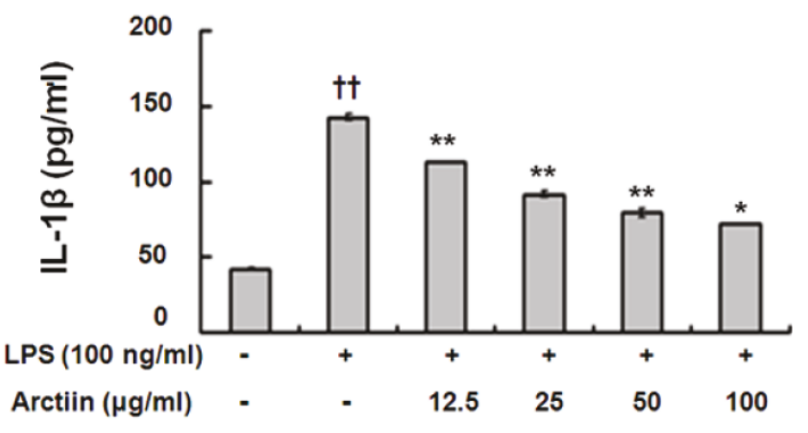

E

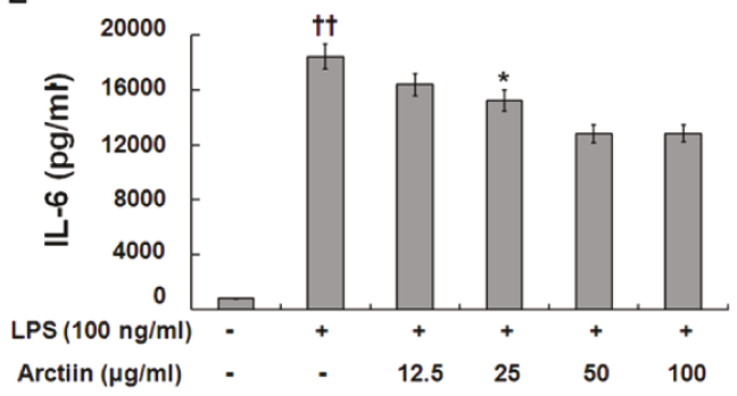

G

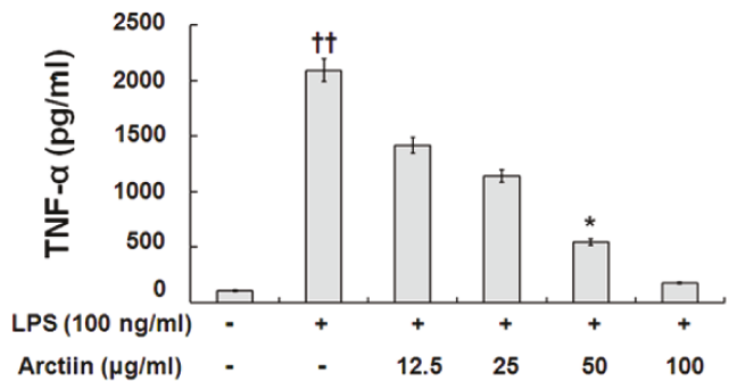

Figure 4 Arctiin inhibits the production of pro-inflammatory cytokines in LPS-stimulated macrophages. RAW 264.7 cells (A:Western blot, $B, D$, and F:ELISA) and primary macrophages (C, E, and G:ELISA) were treated with different concentrations of arctiin $(12.5 \sim 100 \mu \mathrm{g} / \mathrm{ml})$ in the presence of LPS $(100 \mathrm{ng} / \mathrm{ml})$ and was monitored as described in 'Materials and Methods'. Each bar represents the means \pm S.D. from three separate experiments. ${ }^{\dagger} P<0.05,{ }^{t \dagger} P<0.01$ compares to the control. ${ }^{*} P<0.05,{ }^{*} P<0.01$ compared to the LPS. 

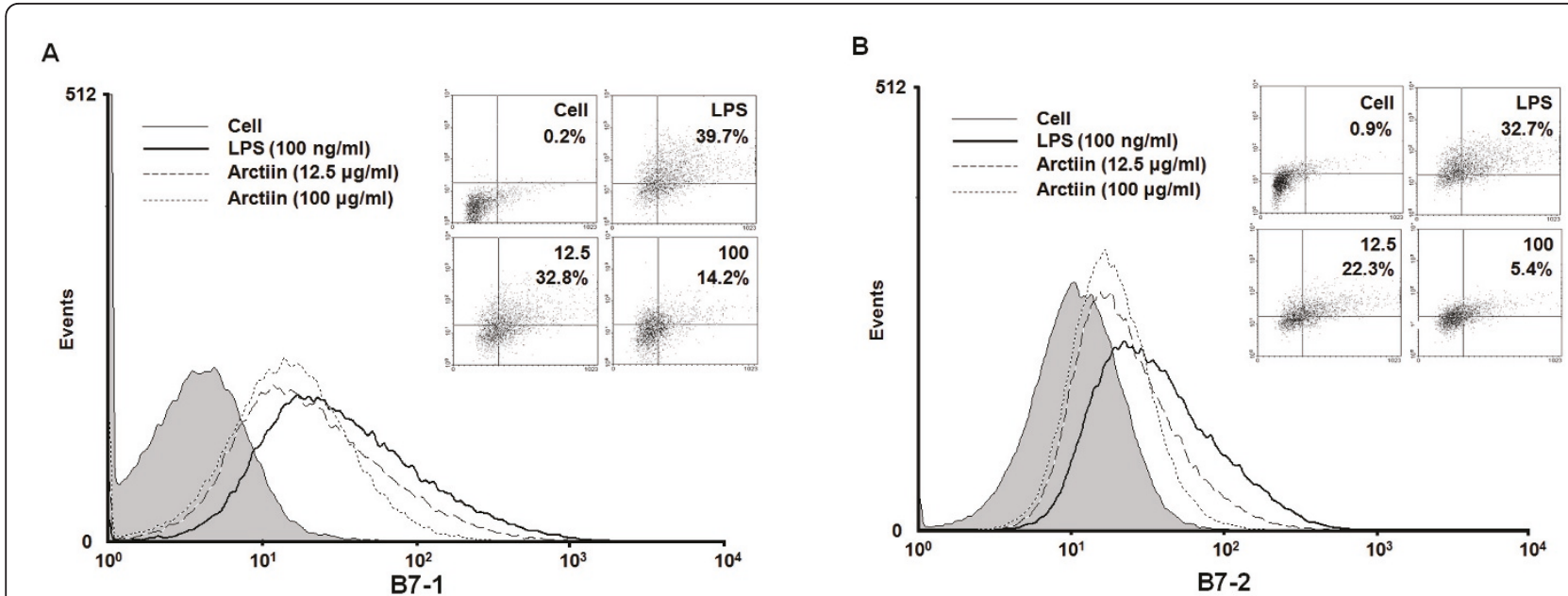

Figure 5 Arctiin inhibits the expression of co-stimulatory molecules in LPS-stimulated macrophages. RAW 264.7 cells (A-B) were treated with different concentrations of arctiin $(12.5 \sim 100 \mu \mathrm{g} / \mathrm{ml})$ in the presence of LPS $(100 \mathrm{ng} / \mathrm{ml})$ and was monitored as described in 'Materials and Methods'. The surface B7-1 (A) and B7-2 (B) molecules were labeled with either anti-B7-1, B7-2 and the cell were stained using anti-VB8.1+8.2FITC, anti-VB2-PE, anti-VB2-FITC (shaded histogram), which served as an isotype control for the nonspecific binding.

\section{Discussion}

Arctiin is lignin compound isolated from Forsythiae Fructus. The anti-cancer $[3,7,8]$ and platelet activating factor antagonistic effects [9] of arctiin have been well documented but the mechanisms underlying anti inflammatory effect are still not understood. The present study found that arctiin significantly inhibited the effects of LPS by suppressing a key inflammatory pathway related to $\mathrm{NF}-\kappa \mathrm{B}, \mathrm{PGE}_{2}$ and NO production, and pro-inflammatory cytokines expression.
Inflammation is a reaction of the body to injury or to infectious, allergic, or chemical irritation. Leukocytes destroy harmful microorganisms and dead cells, preventing the spread of the irritation and permitting the injured tissue to repair itself. However, excessive or persistent inflammation causes a variety of pathological conditions, such as bacterial septic shock, and rheumatoid arthritis $[18,19]$. Inflammatory mediators (e.g. nitric oxide and pro-inflammatory cytokines) have been demonstrated to be critically involved in the development of inflammatory diseases.

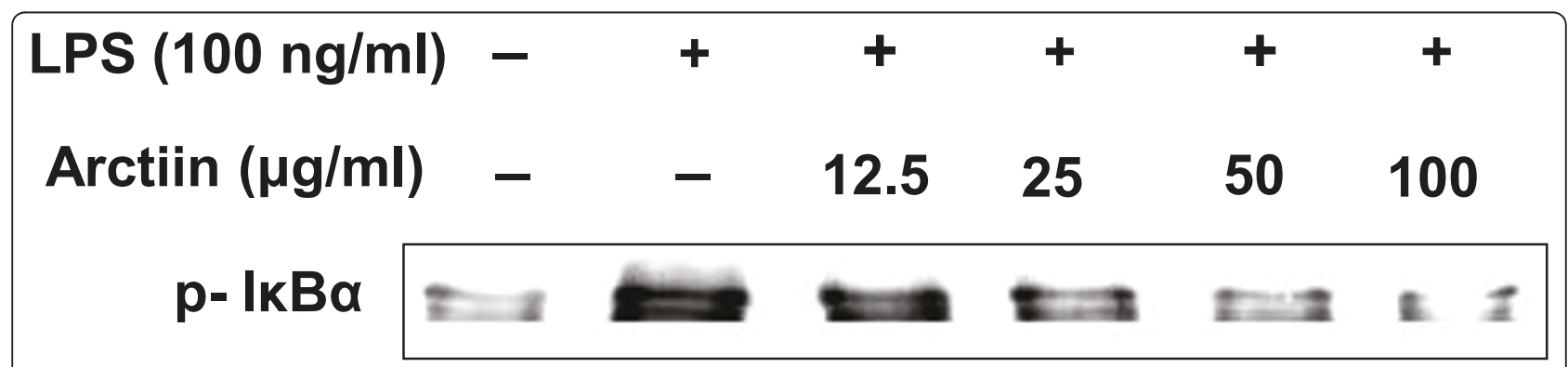

nuclear p65

\section{$\beta$-actin}
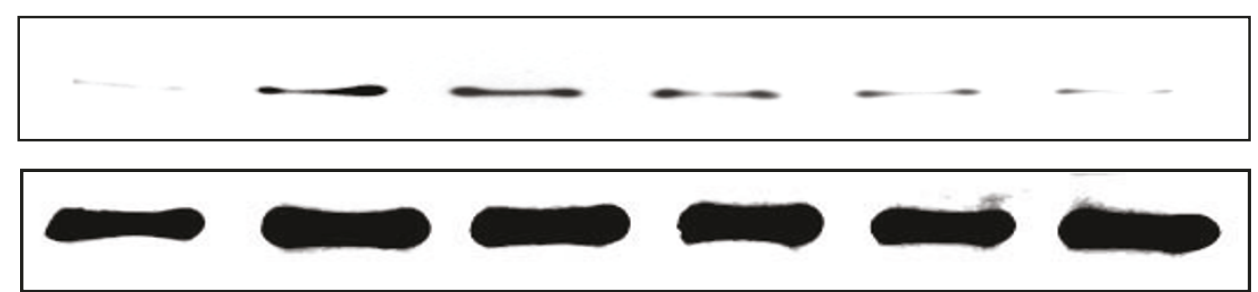

Figure 6 Arctiin inhibits the $\mathrm{I} \kappa \mathrm{B} \alpha$ phosphorylation in cytoplasm and nuclear translocation of NF- $\kappa$ B p65 in LPS-stimulated macrophages. RAW 264.7 cells were treated with different concentrations of arctiin $(12.5 \sim 100 \mu \mathrm{g} / \mathrm{ml})$ in the presence of LPS (100 $\mathrm{ng} / \mathrm{ml})$ and was monitored as described in 'Materials and Methods'. 
Macrophages play important roles in regulating cellmediated immune responses, such as adaptive immune, innate immune, and allergic reactions, as well as inflammation in response to microbes and microbial products such as LPS [20]. In addition to the well-known function of endocytosis, macrophages can be induced to secrete nitric oxide and a series of cytokines including TNF- $\alpha$, IL- $1 \beta$, IL- 6 , and IL-12 that express NF- $\kappa$ Bdependent i-NOS [21,22] and COX-2 [23]. Many diseases, such as arteriosclerosis, chronic hepatitis and pulmonary fibrosis, involve the overproduction of inflammatory mediators [24-27] and thus, inhibiting their production may serve to prevent or suppress a variety of inflammatory diseases, including rheumatoid arthritis (RA), sepsis, and endotoxemia. Despite the exact cause of autoimmune disease remaining obscure, deregulated overproduction of pro-inflammatory cytokines and a disruption in the regulation of cytokine signal transduction have been indicated as underlying mechanisms of some autoimmune diseases such as RA and Crohn's disease [28,29].

Nitric oxide is synthesized via the oxidation of arginine by a family of NOS, and it plays a vital role in regulating physiological processes, such as blood vessel tone and neurotransmission, as well as in host defense and immunity [30,31]. Pro-inflammatory cytokines, IL$1 \beta$, IL- 6 , and TNF- $\alpha$, have attracted more attention in that they can be localized to the infected tissue, manifested systemically throughout the body, and cause vasodilation as well as symptoms of inflammation [32-34]. Our findings that arctiin inhibits the formation of $\mathrm{NO}$ and pro-inflammatory cytokines showed the importance of arctiin as an anti-inflammatory compound. The reduced NO production by arctiin was a consequence of an inhibition of iNOS, the key enzyme responsible for NO production under pathological conditions.

$\mathrm{PGE}_{2}$ plays major roles in the angiogenesis of synovium through the expression of vascular endothelial growth factors [35], synovial inflammation, and joint erosion in RA [36]. Further, in the prostaglandin biosynthesis pathway, COX-2 is the key enzyme that catalyzes the conversion of arachidonic acid to $\mathrm{PGE}_{2}$. It is generally accepted that $\mathrm{PGE}_{2}$ is produced by COX-2 at sites of inflammation, and that COX-1, another constitutive isoform, is relevant in the production of prostaglandins that regulate normal cellular processes such as vascular homeostasis regulation, gastric mucosal protection and renal integrity maintenance [37]. In the present study, we found that arctiin suppressed $\mathrm{PGE}_{2}$ production via inhibition of COX-2 enzyme activity and this may in part be responsible for some of anti-inflammatory properties of this compound.

The transcriptional factor NF- $\kappa \mathrm{B}$ is important for the expression of immune and inflammatory genes. The activated NF- $\kappa \mathrm{B}$ then binds $\kappa \mathrm{B}$ motifs in the promoters via its p65 subunit, leading to expression of several inflammatory genes. Because NF- $\kappa \mathrm{B}$ transcription factors are uniquely positioned downstream of multiple innate and adaptive signaling pathways, they seem ideally placed to integrate and coordinate innate and adaptive signals required for formation of productive immune responses. In the present study, we found that arctiin could inhibit the NF- $\kappa \mathrm{B}$ nucleus translocation induced by LPS through a reduction in $\mathrm{I} \kappa \mathrm{B}$ phosphorylation status.

The B7 family is related immunoglobulin supergene family members that are expressed by multiple cell types involved in antigen presentation. Both B7-1 and B7-2 are constitutively expressed on dendritic cells and are regulated on monocytes, macrophages, B cells, and $\mathrm{T}$ cells following activation. In agreement with our findings, arctiin has also been shown to suppress co-stimulatory molecules such as B7-1 and B7-2 in macrophages.

In summary, these results suggest that arctiin has antiinflammatory effects on macrophages through the reduced pro-inflammatory cytokines are associated with $\mathrm{NF}-\kappa \mathrm{B}$ inactivation and the suppression of NF-kB-regulated proteins, and other bioactive substances as well as through inhibition of the expression of co-stimulatory molecules.

\section{Acknowledgements}

This study was supported by the Sahmyook University Research fund in 2010.

\section{Author details}

${ }^{1}$ College of Pharmacy, SahmYook University, Seoul 139-742, Republic of Korea. ${ }^{2}$ School of Life Sciences, Handong Global University, Pohang 791-708, Republic of Korea. ${ }^{3}$ College of Pharmacy, Chungbuk National University, Cheongju 361-763, Republic of Korea.

\section{Authors' contributions}

$\mathrm{SL}$ participated in the design of this study and performed the statistical analysis in whole research. SS carried out the Western blot assay of iNOS, COX-2, and proinflammatory cytokines. HK carried out the RT-PCR assay. SH carried out the FACS analysis in B7 family. KK carried out the preparation of peritoneal macrophages, participated in the maintenance of SPF room and care of animal. JK carried out the cytokine assay (ELISA). JHK participated in the design of the study, and proofread a manuscript about in vitro experiments design. CKL participated in the design of the study, and proofread a manuscript about in vivo experiments design. NJH participated in the test of toxicity of this compound, and proofread a manuscript about cell toxicity. DY carried out the separation of arctiin from Forsythiae Fructus. KK conceived of the study, and participated in its design and coordination. All authors read and approved the final manuscript.

\section{Competing interests}

The authors declare that they have no competing interests.

\section{Received: 17 June 2010 Accepted: 7 July 2011 Published: 7 July 2011}

\section{References}

1. Lee Gl, Ha JY, Min KR, Nakagawa H, Tsurufuji S, Chang IM: Inhibitory effects of oriental herbal medicines on IL-8 induction in lipopolysaccharideactivated rat macrophages. Planta Med 1995, 61(1):26-30. 
2. Kim TJ: Korean resources plants. Seoul „, first 1991.

3. Huang DM, Shen YC, Wu C, Huang YT, Kung FL, Teng CM, Guh JH: Investigation of extrinsic and intrinsic apoptosis pathways of new clerodane diterpenoids in human prostate cancer PC-3 cells. Eur J Pharmacol 2004, 503(1-3):17-24.

4. Macrae WD, Tower GH: Biological activities of Lignans. Phytochemistry 1984, 23:1207-1220.

5. Morita K, Nishijima Y, Kada T: Chemical nature of a desmutagenic factor from Burdock (Arctium lappa Linne). Agr Biol Chem 1985, 49:925-932.

6. Kazuki S, Seikichi K, Misao M, Zwe-Ling K, Hiroshi H: Antimutagenicity of Dialyzates of Vegetables and Fruits (Food \& Nutrition). Agr Biol Chem 1988, 52:1369-1375.

7. Ryu S, Ahn J, Kang Y, Han B: Antiproliferative effect of arctigenin and arctiin. Arch Pharmacol Res 1995, 18:462-463.

8. Moritani S, Nomura M, Takeda Y, Miyamoto K: Cytotoxic components of bardanae fructus (goboshi). Biol Pharm Bull 1996, 19:1515-1517.

9. Iwakami S, Wu JB, Ebizuka Y, Sankawa U: Platelet activating factor (PAF) antagonists contained in medicinal plants: lignans and sesquiterpenes. In Chem Pharm Bull. Volume 40. Tokyo; 1992:1196-1198.

10. Ichikawa K, Kinoshita T, Nishibe S, Sankawa U: The Ca2+ activity of lignans. Chem Pharm Bull 1986, 34:3514-3517.

11. Liu S, Chen K, Schliemann W, Strack D: Isolation and identification of arctiin and arctigenin in leaves of burdock (Arctium lappa L.) by polyamide column chromatography in combination with HPLC-ESI [sol] MS. Phytochem Anal 2005, 16:86-89.

12. Minagar A, Shapshak P, Fujimura R, Ownby R, Heyes M, Eisdorfer C: The role of macrophage/microglia and astrocytes in the pathogenesis of three neurologic disorders: HIV-associated dementia, Alzheimer disease, and multiple sclerosis. J Neurol Sci 2002, 202:13-23.

13. Stevens DL: Immune modulatory effects of antibiotics. Curr Opin Infec Dis 1996, 9:165-169.

14. Nathan C: Nitric oxide as a secretory product of mammalian cells. FASEB J 1992, 6:3051-3064.

15. Sharpe AH, Freeman GJ: The B7-CD28 superfamily. Nat Rev Immunol 2002, 2:116-126

16. Gomez PF, Pillinger MH, Attur M, Marjanovic N, Dave M, Park J: Resolution of inflammation: prostaglandin E2 dissociates nuclear trafficking of individual NF-kappaB subunits (p65, p50) in stimulated rheumatoid synovial fibroblasts. J Immunol 2005, 175:6924-6930

17. Strayhorn WD, Wadzinski BE: A novel in vitro assay for deubiquitination of I kappa B alpha. Arch Biochem Biophys 2002, 400:76-84.

18. Dinarello C: Proinflammatory and anti-inflammatory cytokines as mediators in the pathogenesis of septic shock. Chest 1997, 112:321S-329S.

19. Palladino M, Bahjat F, Theodorakis E, Moldawer L: Anti-TNF-alpha therapies: the next generation. Nat Rev Drug Discov 2003, 2:736-746.

20. Firestein GS: Invasive fibroblast-like synoviocytes in rheumatoid arthritis. Passive responders or transformed aggressors? Arthritis Rheum 1996, 39:1781-1790.

21. Nathan C: Inducible nitric oxide synthase: what difference does it make? J Clin Invest 1997, 100:2417-2423.

22. Bogdan C: Nitric oxide and the immune response. Nat Immunol 2001, 2:907-916.

23. Vila-del Sol V, Fresno M: Involvement of TNF and NF-kappa B in the transcriptional control of cyclooxygenase-2 expression by IFN-gamma in macrophages. J Immunol 2005, 174:2825-2833.

24. Isomaki P, Punnonen J: Pro- and anti-inflammatory cytokines in rheumatoid arthritis. Ann Med 1997, 29:499-507.

25. Libby $P$, Ridker $P$, Maseri A: Inflammation and atherosclerosis. Am Heart Assoc 2002, 150:1135-1143.

26. Tilg H, Wilmer A, Vogel W, Herold M, Nolchen B, Judmaier G: Serum levels of cytokines in chronic liver diseases. Gastroenterology 1992, 103:264-274.

27. Coker RK, Laurent GJ: Pulmonary fibrosis: cytokines in the balance. Eur Respir J 1998, 11:1218-1221.

28. Chenevier-Gobeaux C, Morin-Robinet S, Lemarechal H, Poiraudeau S, Ekindjian JC, Borderie D: Effects of pro- and anti-inflammatory cytokines and nitric oxide donors on hyaluronic acid synthesis by synovial cells from patients with rheumatoid arthritis. Clin Sci (Lond) 2004, 107:291-296.

29. Nishimoto $\mathrm{N}$ : Cytokine signal regulation and autoimmune disorders. Autoimmunity 2005, 38:359-367
30. Furchgott R, Cherry P, Zawadzki J, Jothianandan D: Endothelial cells as mediators of vasodilation of arteries. J Cardiovasc Pharmacol 1984, 6 S336-343.

31. Wei $X$, Charles I, Smith A, Ure J, Feng G, Huang H: Altered immune responses in mice lacking inducible nitric oxide synthase. Nature 1995, 375:408-4011.

32. Haddad JJ, Safieh-Garabedian B, Saadé NE, Kanaan SA, Land SC: Chemioxyexcitation (delta pO2/ROS)-dependent release of IL-1 beta, IL-6 and TNF-alpha: evidence of cytokines as oxygen-sensitive mediators in the alveolar epithelium. Cytokine 2001, 13:138-147.

33. Moldoveanu A, Shephard R, Shek P: Exercise elevates plasma levels but not gene expression of IL-1 $\beta, I L-6$, and TNF- $\alpha$ in blood mononuclear cells. J Appl Physiol 2000, 89:1499-1504.

34. Ben-Av P, Crofford L, Wilder R, Hla T: Induction of vascular endothelia growth factor expression in synovial fibroblasts by prostaglandin $\mathrm{E}$ and interleukin-1: a potential mechanism for inflammatory angiogenesis. FEBS Lett 1995, 372:83-87

35. Dayer J: Prostaglandin production by rheumatoid synovial cells: stimulation by a factor from human mononuclear Cells. J Exp Med 1977, 145:1399-1404

36. Lecomte M, Laneuville O, Ji C, DeWitt D, Smith W: Acetylation of human prostaglandin endoperoxide synthase-2 (cyclooxygenase-2) by aspirin. Biol Chem 1994, 269:13207-13215.

37. Vane J, Bakhle Y, Botting R: Cyclooxygenases 1 and 2. Annu Rev Pharmacol Toxicol 1998, 38:97-120.

doi:10.1186/1476-9255-8-16

Cite this article as: Lee et al: Anti-inflammatory function of arctiin by inhibiting COX-2 expression via NF- $\kappa$ B pathways. Journal of Inflammation $20118: 16$

\section{Submit your next manuscript to BioMed Central and take full advantage of:}

- Convenient online submission

- Thorough peer review

- No space constraints or color figure charges

- Immediate publication on acceptance

- Inclusion in PubMed, CAS, Scopus and Google Scholar

- Research which is freely available for redistribution

Submit your manuscript at www.biomedcentral.com/submit
C) Biomed Central 